\title{
THE INFLUENCE OF ONLINE INFORMATION SOURCE ON ATTITUDE, INFORMATION ADOPTION, AND PURCHASE INTENTION : STUDY IN CONSUMER CANDIDATE OF CAR PRODUCT IN BANDA ACEH
}

\author{
Sri Wahyuni, Permana Honneyta Lubis and Sorayati Utami \\ Department of Management, UniversitasSyiah Kuala, Indonesia \\ http://doi.org/10.35409/IJBMER.2019.2426
}

\begin{abstract}
This study aims to examine the influence of online information source on attitude, information adoption and purchase intention. The object is the people in Banda Aceh that are as the costumer candidates that have the purchase intention to buy a car, and search the information of cars by the internet. The sample is taken using purposive sampling technique, and it provides 180 respondents. The data is analyzed using SEM-Partial Least Square and it is processed by using SmartPLS software. The result shows that online information source influences purchase intention significantly, online information source influences attitude significantly, online information source influences information adoption significantly, attitudes influences purchase intention significantly, attitudes influences purchase intention significantly, and information adoption influences purchase intention significantly. These findings contribute to the realm of science that succeed building the model, and can be a reference to develop another model in the further. The originality rests in the combination of the causality theories form the previous, and uses SEM-Partial Least Square as a statistic test technique. The limitation resides in the amount of the variables and object
\end{abstract}

Keyword: Online Information Source, Attitude, Information Adoption, Purchase Intention

\section{INTRODUCTION}

According to (Martins et al., 2019) purchase intention is the likelihood of someone having a plan or wish to buy a certain product or service in the future. The development of purchase intentions reflects an opportunity to make a purchase, if consumers have a large purchase intention for a product or service, then that will encourage consumers to make purchasing decisions. According to (Hwang and Zhang, 2018), purchase intention is the intention of consumers to buy products or services based on subjective evaluations with general evaluations that serve as the main motivation of buying behavior.

There are five stages in the purchase process that are passed by consumers according to (Kotler and Keller, 2018) namely the stage where consumers recognize their needs, then search for information, consumers evaluate other alternative choices, consumers make the decision to purchase, and post-purchase behavior that is satisfied or not. In making the decision to buy luxury goods such as cars, the consumer will go through five stages of the buying process. 


\section{International Journal of Business Management and Economic Review}

Vol. 2, No. 06; 2019

ISSN: 2581-4664

The purchase decision process by going through these five processes is needed when consumers purchases products or services that require high consideration due to the importance of the product. Consumers will think of various brands and look for various information needed before buying a luxury product such as a car, consumers will think in detail the differences from other alternative products by setting certain criteria such as fuel-saving, high durability, equipment, specifications, features of a product, and also compare prices using either online information sources or offline information sources.

The process of finding information on the internet or online can be done by consumers through personal computers or mobile phones and this information in form of written, video, and photos of a brand. While searching for information online can directly go to dealers, sales, newspapers, magazines, family or friends. Information about the brand is needed by consumers to avoid dissatisfaction after making a purchase.

Information seeking is encouraged to develop more consumer knowledge regarding product, brand, store, and price information (Peter and Olson, 2013). Information technology that continues to grow influences the attitudes and lifestyles of people who increasingly need fast and accurate information. Many media can be used such as newspapers, websites, online newspapers, radio broadcasts, magazines, tv but the internet is becoming a media that is considered fast in providing information. According to (Mahkota, Suyadi and Riyadi, 2014) using the internet at the present time is considered as part of the lifestyle of consumers in the world including in Indonesia.

Every year, the number of internet users in Indonesia has increased, in 2016 the number of internet users was 3.25 billion people, in 2017 there were 3.773 million people and in 2018 there were 4.021 million people. There is a relationship between the high growth of the internet in Indonesia and the rate of growth of the automotive industry. So far in the automotive industry believe in the "buying range". During this time, after seeing a car ad, prospective consumers need more time, that is, for six months to finally make a decision to buy.

However, research conducted by iCar Asia (iCar Digital Shift Research) revealed different results where that was as many as $87 \%$ of prospective car buyers in Indonesia used the internet as a source of looking for the least information before visiting dealers, and the they took three months to search the information related(Cakdan, 2013).

The existence of the internet changes the habits of prospective buyers, first if people want to buy a car, people come directly to the showroom. However, with the internet, $67 \%$ of people do it by searching on search engines ranging from the most economical, cheapest, and most comfortable. They try to find information about the latest promos, car reviews, until the price incurred.It is also found $83 \%$ of potential buyers made their choice after seeing a commercial video launched by a brand. And $72 \%$ of themcame directly to the dealer to do a driving test(Cakdan, 2013)

In making a purchase decision for a product, consumers also first consult with others to get more information related to the product. According to (Thuarau et al., 2004), the development on the internet has also changed the habits of people in communication so far we know the communication of Word of Mouth (WOM) into Electronic Word of Mouth communication, which is a change from traditional communication to modern communication.

Communication with e-WOM uses online chatrooms such as KASKUS (online community), OLX (online shop), blogs, social media, news sites, web forums, via rooms as 


\section{International Journal of Business Management and Economic Review}

Vol. 2, No. 06; 2019

ISSN: 2581-4664

online media to search for brand recommendations from experts, or their experiences already visit the manufacturing site and who are already using the product. However, the type and source of information related to the product will provide a meaningful function to dominate in shaping buying decisions.

E-WOM activity is a phenomenon of consumer behavior based on the development of online marketing. Of the two elements of AISAS theory, that is, the search and share element, when consumers share a review of a product or service that has been used and produce the term WOM online, known as e-WOM (Yani, Ceng and Priskilla, 2013).

According to (Alboqami et al., 2015) in addition to consumers, sellers or producers can also provide information on their company's official website, thus prospective buyers will get information through online information sources such as eWOM. Consumers who get information online also need to comprehensively understand information so that potential buyers can adopt information in shaping their purchase intentions.

The informationadoption stems from technology adoption theory, which refers to the process of selecting, evaluating, receiving and objectively utilizing information, and that the process will ultimately influence the subject's follow-up behavior. The usefulness of information is a key construction in adoption behavior (Sussman and Siegal, 2003).

This study aims to see how the source of information can make prospective buyers can adopt the information received and can influence purchase intentions in the future. According to (Cheung and Thadani, 2012) people tend to trust information from sources that are very credible and are more ready to receive information because if the source has low credibility, recipients tend not to receive that information. (Erkan and Evans, 2016) in their research explained that consumers who adopt information are more likely to have purchase intentions.

In the research of (Chen et al., 2016)explained that consumers can use e-WOM information sources, neutral website sources, and producer website sources to accommodate information about brands and products. This online information source influences attitude and significantly influences the purchase intention for a product brand. The ability of prospective buyers to recognize needs sought from information media plays an important role in shaping attitudes and adopting information and its impact on purchase intentions.

\section{LITERATURE REVIEW \\ Purchase Intention}

Purchase intention is part of a person's behavior in his attitude to consume or one's tendency to think before actually deciding to buy (Kinnear and Taylor, 2002). (Meskaran, Ismail and Shanmugam, 2013) mentioned that the difference between buying and buying intentions is when buying is a buying process that has been done while the purchase intention is a new purchase that will be planned and carried out in the future.

Purchase intention is process to analyze and predict consumer behavior related to their willingness to buy, to use, and pay attention to a particular brand (Imari, Lubis and Chen, 2017). Purchase intention is the possibility of someone intending to buy a product or service offered or not (Utami, Ma'ruf and Utami, 2017).

\section{Online Information Source}

According to (Kurniawan, 2005) online information media are online-based media that 


\section{International Journal of Business Management and Economic Review}

Vol. 2, No. 06; 2019

ISSN: 2581-4664

are read through computers and connected to the internet network. Examples such as manufacturer websites, neutral websites, TV, online newspapers, and others.

The advancement of Web 2.0 makes it easy for consumers to share experiences, opinions, and feedback about products, services, or brands in the form of product evaluations for other consumers. Consumer online reviews, which are electronic versions or electronic word of mouth, are becoming increasingly known and preferred by consumers around the world today, they read these reviews before making a purchase decision (Filieri, 2015). In addition to consumer review platforms such as e-WOM, websites also influence the formation of consumer buying decisions. In this study the authors took 3 online information sources, namely: (1) Electronic Word Of Mouth (e-WOM); (2) neutral website, (3) manufacturer's website, which will be explained in the following sub-chapter:

1. $\mathrm{e}-\mathrm{WOM}$

e-WOM is the exchange of product or service evaluations among people who meet, talk, and text with each other in the world (Wang et al., 2016). Consumers can exchange productrelated information with other users through their experiences through chat rooms or web forums, thus enabling them to share and facilitate their knowledge and experiences with each other (Chen et al., 2016)

2. Neutral Website

Chen et al., (2016) showed that a product valuation website is considered a neutral website. These sources provide consumers with information that includes brand comparisons with reference to sales ratings, expert opinions on brand recommendations and relevant special reports such as www.mobil123.com and carmudi.co.id. According to a study by (Chen et al., 2016) third-party sources are highly valued by consumers because they facilitate consumers' external search efforts by reducing search costs.

\section{Producer Website}

(Mccole, Ramsey and Williams, 2010) in (Chen et al., 2016) In order to reduce the uncertainty and perceived risk associated with online purchases, consumers can turn to the manufacturer's website for more detailed information including prices, discount promotions, product descriptions, advertisements, after-purchase services about a product for example like www.honda-mobil.com and www.toyota.astra.co.id. Consumers who seek information from producer website sources are interested in getting objective factual information about product and service brand attributes.

\section{Attitude}

Planned behavior theory claims that the more positive the attitude towards a particular behavior is the more likely an individual is to perform that behavior (Sreen, Purbey and Sadarangani, 2018). Conceptually, attitude is a determinant of emotion and also intention (Marticotte and Arcand, 2017). (Dwipayani and Rahyuda, 2016) define attitude as someone's depiction of an object and influence its behavior on the object.

\section{Information Adoption}

Information adoption defined by (Zhang and Watts, 2008) is the extent to which a person 


\section{International Journal of Business Management and Economic Review}

Vol. 2, No. 06; 2019

ISSN: 2581-4664

can accept the contents of the message and believe that the information is meaningful after assessing the contents of the information. This definition is an individual-level information processing perspective that considers how meaning is related to content received when the context is not interactive or explicitly educating.

(Charo et al., 2015) defined information adoption as a tendency for people to make use of information available online. Adoption of information is also a practice where people intentionally with certain motives are involved in utilizing the information available on the internet. Information adoption behavior is basically one of the main activities of consumers searching for information in online communities (Farid and Yanti, 2018).

\section{Research Model and Hypothesis}

The following is an research model and hypothesis of this study.

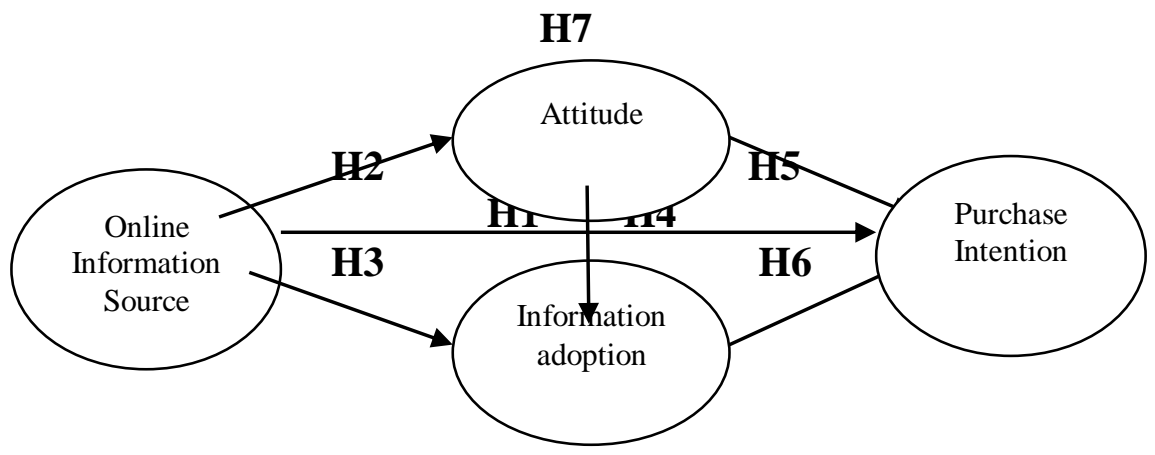

Figure 1. Research Model

\section{Hypothesis}

$\mathrm{H} 1$ : online information source influences purchase intention significantly,

$\mathrm{H} 2$ : online information source influences attitude significantly,

H3 : online information source influences information adoption significantly,

H4 : attitude influences information adoption significantly,

H5 : attitude influences purchase intention significantly, and,

H6 : information adoption influences purchase intention significantly.

\section{RESEARCH METHOD}

The location of this research is in the city of Banda Aceh and the variables are nOnline Information Sources (X), Purchase Intention (Y), Attitudes (Z1) and Information Adoption $\left(\mathrm{Z}_{2}\right)$. The population is the people of Banda Aceh City who will buy car products and use online information sources to find information about cars, and sampling is taken using the nonprobability sampling method, which is a purposive sampling technique. And the sample in this study is 180 respondents. 


\section{RESULT}

Table 1. Demographic Characteristics of the Sample

\begin{tabular}{|c|c|c|c|}
\hline No & Variable & Frequency & Percent \\
\hline \multirow[t]{2}{*}{1} & $\begin{array}{l}\text { Gender: } \\
\text { 1. Male } \\
\text { 2. Female }\end{array}$ & $\begin{array}{c}104 \\
76\end{array}$ & $\begin{array}{l}57.8 \% \\
42.2 \%\end{array}$ \\
\hline & Total & 180 & $100 \%$ \\
\hline \multirow[t]{2}{*}{2} & $\begin{array}{l}\text { Personal Status: } \\
\text { 1. Married } \\
\text { 2. Single } \\
\text { 3. Widower } \\
\text { 4. Widow }\end{array}$ & $\begin{array}{c}87 \\
92 \\
1 \\
0\end{array}$ & $\begin{array}{c}48.3 \% \\
51.1 \% \\
0.6 \% \\
0\end{array}$ \\
\hline & Total & 180 & $100 \%$ \\
\hline \multirow[t]{2}{*}{3} & $\begin{array}{l}\text { Age of Respondents: } \\
1.25-29 \text { year } \\
2.30-34 \text { year } \\
3.35-39 \text { year } \\
4 .>40 \text { year }\end{array}$ & $\begin{array}{c}73 \\
68 \\
32 \\
7 \\
\end{array}$ & $\begin{array}{c}34.1 \% \\
31.8 \% \\
15 \% \\
3.3 \% \\
\end{array}$ \\
\hline & Total & 180 & $100 \%$ \\
\hline \multirow[t]{2}{*}{4} & $\begin{array}{l}\text { Education: } \\
\text { 1. High School } \\
\text { 2. Diploma } \\
\text { 3. Bachelor (S1) } \\
\text { 4. Post-graduate (S2) } \\
\text { 5. Others }\end{array}$ & $\begin{array}{l}26 \\
24 \\
96 \\
17 \\
17\end{array}$ & $\begin{array}{c}12.1 \% \\
11.2 \% \\
44.9 \% \\
7.9 \% \\
7.9 \%\end{array}$ \\
\hline & Total & 180 & $100 \%$ \\
\hline \multirow[t]{2}{*}{5} & $\begin{array}{l}\text { Pekerjaan: } \\
\text { 1. Civil Servants } \\
\text { 2. Army } \\
\text { 3. Employees } \\
\text { 4. Businessman } \\
\text { 5. Police } \\
\text { 5. Others } \\
\end{array}$ & $\begin{array}{c}37 \\
4 \\
64 \\
50 \\
18 \\
7\end{array}$ & $\begin{array}{c}17.3 \% \\
1.9 \% \\
29.9 \% \\
23.4 \% \\
8.4 \% \\
3.3 \% \\
\end{array}$ \\
\hline & Total & 180 & $100 \%$ \\
\hline \multirow[t]{2}{*}{6} & $\begin{array}{l}\text { Income (per Month): } \\
\text { 1. Rp.7.000.000-7.999.000 } \\
\text { 2. Rp 8.000.000-8.999.000 } \\
\text { 3. Rp 9.000.000-9.999.000 } \\
\text { 4. Rp 10.000.000-10.999.000 } \\
\text { 5. >Rp 15.000.000 }\end{array}$ & $\begin{array}{l}49 \\
58 \\
46 \\
15 \\
12\end{array}$ & $\begin{array}{c}27.2 \% \\
32.2 \% \\
25.6 \% \\
8.3 \% \\
6.7 \%\end{array}$ \\
\hline & Total & 180 & $100 \%$ \\
\hline
\end{tabular}

Source: Output of SPSS (2019) 


\section{International Journal of Business Management and Economic Review}

Vol. 2, No. 06; 2019

ISSN: 2581-4664

\section{Measurement Model (Outer Model)}

What is seen in the outer model testing is the relationship between the indicator value to the variable by looking at the value of its validity and reliability. There are two components analyzed in Validity, namely: (1) loading factor and AVE, and (2) AVE roots and inter-variable correlation. Meanwhile, to measure reliability is assessed by looking at the value of composite reliability and Cronbach's alpha (F. Hair Jr et al., 2014). By using SmartPLS, the test provides the outputsof loading indicator from the variables have fulfilled the requirements. Forthe convergent validity, the value is above 0.7 , and the AVE valueis also above 0.50 , both has fulfilled the requirements (F. Hair Jr et al., 2014). The output of loading indicator and AVE value can be seen in Figure 2 below:

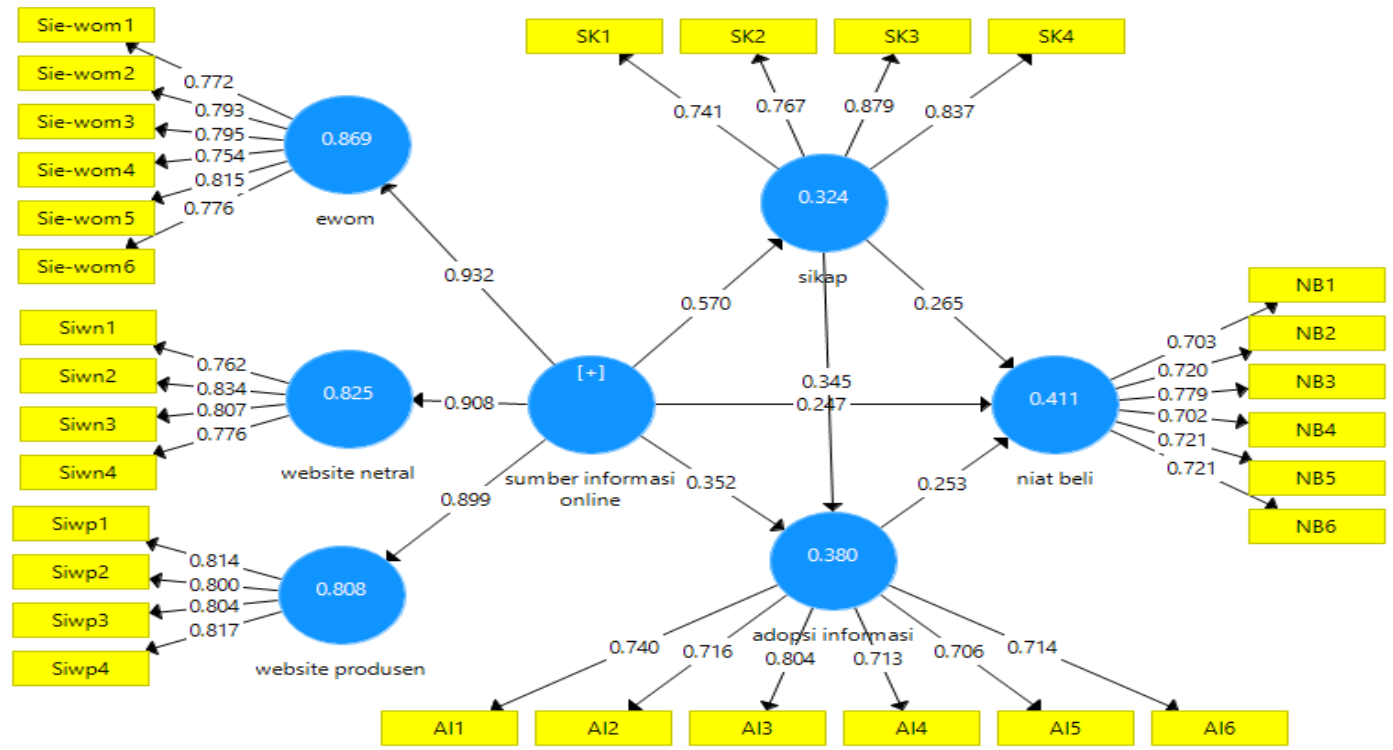

Source: Output of SmartPLS (2019)

Figure 2. Loading Indicator Output

Table 2.AVE

\begin{tabular}{|l|l|}
\hline \multicolumn{1}{|c|}{ Variable } & AVE \\
\hline Online Information Source & 0.529 \\
\hline Attitude & 0.653 \\
\hline Information Adoption & 0.537 \\
\hline Purchase Intention & 0.525 \\
\hline
\end{tabular}

Discriminant Validity Test

The result shows that it has a good discriminant validity value if the cross-loading value of the variable is greater compared to other variables, and the root value of AVE is greater than the square value of the variable correlation, which is explained as follows: 
International Journal of Business Management and Economic Review

Vol. 2, No. 06; 2019

ISSN: 2581-4664

Tabel 3. Cross Loadings

\begin{tabular}{|c|c|c|c|c|}
\hline Indicator & $\begin{array}{c}\text { Online } \\
\text { Information } \\
\text { Source }\end{array}$ & Attitude & $\begin{array}{c}\text { Information } \\
\text { Adoption }\end{array}$ & $\begin{array}{c}\text { Purchase } \\
\text { Intention }\end{array}$ \\
\hline sie-wom1 & $\mathbf{0 . 7 2 7}$ & 0.341 & 0.363 & 0.447 \\
\hline sie-wom2 & $\mathbf{0 . 7 2 0}$ & 0.429 & 0.460 & 0.448 \\
\hline sie-wom3 & $\mathbf{0 . 7 1 4}$ & 0.453 & 0.386 & 0.414 \\
\hline sie-wom4 & $\mathbf{0 . 7 1 7}$ & 0.482 & 0.448 & 0.417 \\
\hline sie-wom5 & $\mathbf{0 . 7 4 0}$ & 0.427 & 0.418 & 0.399 \\
\hline sie-wom6 & $\mathbf{0 . 7 6 5}$ & 0.391 & 0.419 & 0.398 \\
\hline siwn1 & $\mathbf{0 . 7 0 9}$ & 0.435 & 0.404 & 0.418 \\
\hline siwn2 & $\mathbf{0 . 7 3 4}$ & 0.398 & 0.398 & 0.409 \\
\hline siwn3 & $\mathbf{0 . 7 3 3}$ & 0.374 & 0.399 & 0.299 \\
\hline siwn4 & $\mathbf{0 . 7 1 2}$ & 0.413 & 0.409 & 0.313 \\
\hline siwp1 & $\mathbf{0 . 7 4 4}$ & 0.420 & 0.379 & 0.410 \\
\hline siwp2 & $\mathbf{0 . 7 2 3}$ & 0.406 & 0.377 & 0.393 \\
\hline siwp3 & $\mathbf{0 . 7 1 8}$ & 0.396 & 0.388 & 0.360 \\
\hline siwp4 & $\mathbf{0 . 7 2 2}$ & 0.433 & 0.329 & 0.334 \\
\hline sk1 & 0.415 & $\mathbf{0 . 7 3 4}$ & 0.428 & 0.348 \\
\hline sk2 & 0.407 & $\mathbf{0 . 7 7 2}$ & 0.370 & 0.409 \\
\hline sk3 & 0.527 & $\mathbf{0 . 8 8 3}$ & 0.452 & 0.487 \\
\hline sk4 & 0.481 & $\mathbf{0 . 8 3 6}$ & 0.501 & 0.495 \\
\hline Ai1 & 0.493 & 0.511 & $\mathbf{0 . 7 4 0}$ & 0.400 \\
\hline Ai2 & 0.351 & 0.364 & $\mathbf{0 . 7 1 6}$ & 0.385 \\
\hline Ai3 & 0.444 & 0.400 & $\mathbf{0 . 8 0 4}$ & 0.392 \\
\hline Ai4 & 0.381 & 0.402 & $\mathbf{0 . 7 1 3}$ & 0.360 \\
\hline Ai5 & 0.358 & 0.308 & $\mathbf{0 . 7 0 6}$ & 0.341 \\
\hline Ai6 & 0.357 & 0.375 & $\mathbf{0 . 7 1 4}$ & 0.453 \\
\hline nb1 & 0.348 & 0.416 & 0.380 & $\mathbf{0 . 7 0 3}$ \\
\hline nb2 & 0.337 & 0.429 & 0.417 & $\mathbf{0 . 7 2 0}$ \\
\hline nb3 & 0.415 & 0.457 & 0.419 & $\mathbf{0 . 7 7 9}$ \\
\hline nb4 & 0.412 & 0.358 & 0.365 & $\mathbf{0 . 7 0 2}$ \\
\hline nb5 & 0.415 & 0.352 & 0.323 & $\mathbf{0 . 7 2 1}$ \\
\hline nb6 & 0.409 & 0.342 & 0.404 & $\mathbf{0 . 7 2 1}$ \\
\hline & & & & \\
\hline
\end{tabular}

It can be seen from the table above that indicator of online information sources, attitudes, information adoption and purchase intentions have a higher correlation with their respective variables compared to other variables. This means that it can be said that the variables in this study have good discriminant validity. 


\section{International Journal of Business Management and Economic Review}

Vol. 2, No. 06; 2019

ISSN: 2581-4664

Table 4. Correlation between Variabels

\begin{tabular}{|l|c|c|c|c|}
\hline Research Variables & $\begin{array}{c}\text { Purchase } \\
\text { Intention }\end{array}$ & Attitude & $\begin{array}{c}\text { Information } \\
\text { Adoption }\end{array}$ & $\begin{array}{c}\text { Online Information } \\
\text { Source }\end{array}$ \\
\hline Purchase Intention & & & & \\
\hline Attitude & 0.265 & & 0.345 & \\
\hline $\begin{array}{l}\text { Information } \\
\text { Adoption }\end{array}$ & 0.253 & & & \\
\hline $\begin{array}{l}\text { Online Information } \\
\text { Source }\end{array}$ & 0.247 & 0.570 & 0.352 & \\
\hline
\end{tabular}

Table 5. AVE and AVE Root

\begin{tabular}{|l|c|c|}
\hline \multicolumn{1}{|c|}{ Research Variables } & $\begin{array}{c}\text { Average Variance Extracted } \\
\text { (AVE) }\end{array}$ & AVE Root \\
\hline Online Information Source & 0.529 & 0.7273 \\
\hline Attitude & 0.653 & 0.8081 \\
\hline Information Adoption & 0.537 & 0.7328 \\
\hline Purchase Intention & 0.525 & 0.7245 \\
\hline
\end{tabular}

In this study, the correlation of online information source and the purchase intention of 0.247 , attitude of 0.570 , and the adoption of information of 0.352 are smaller than the value of AVE root that is 0.7273 . The correlation between the attitude and purchase intention is 0.265 , correlation attitude and information adoption is 0.345 smaller than the root value of AVE which is 0.8081 . The correlation between information adoption and purchase intention is 0.253 and smaller than AVE root value, whichis 0.7328. Because the AVE root value of the four variables above is greater than the correlation value between variables, it can be said that the variables in this study have good discriminant validity.

Reliability Test

In the reliability test, what is assessed is composite reliability and Cronbach's alpha. Composite reliability must have a value> 0.70 and Cronbach's alpha> 0.60 (Abdillah and Jogiyanto, 2015). The reliability test results in this study will be explained as follows:

Table 6.Reliability Test

\begin{tabular}{|c|l|c|c|c|}
\hline No. & \multicolumn{1}{|c|}{ Variables } & Composite Reliability & $\begin{array}{c}\text { Cronbach's } \\
\text { Alpha }\end{array}$ & Remarks \\
\hline 1. & Online Information Source & 0.940 & 0.931 & Reliable \\
\hline 2. & Attitude & 0.882 & 0.822 & Reliable \\
\hline 3. & Information Adoption & 0.874 & 0.828 & Reliable \\
\hline 4. & Purchase Intention & 0.869 & 0.819 & Reliable \\
\hline
\end{tabular}

\section{Structural Model Test (Inner Model)}

Testing in the inner model aims to see the relationship between variables andthe 


\section{International Journal of Business Management and Economic Review}

Vol. 2, No. 06; 2019

ISSN: 2581-4664

significance values, R-square, F-square, and Q2. A high R-square value indicates a good relationship between variables. The following is the R-Square Value:

Table 7.R-square Result

\begin{tabular}{|l|c|c|}
\hline \multicolumn{1}{|c|}{ Research Variables } & $\mathbf{R}^{\mathbf{2}}$ & $\mathbf{R}^{\mathbf{2}}$ Adjusted \\
\hline Online Information Source & 0.000 & 0.000 \\
\hline Attitude & 0.324 & 0.373 \\
\hline Information Adoption & 0.380 & 0.373 \\
\hline Purchase Intention & 0.411 & 0.401 \\
\hline
\end{tabular}

$\mathrm{R}^{2}$ value on the attitude variable of 0.324 means that the online information source is able to explain the attitude of $32.4 \%$, and $67.6 \%$ is influenced by other variables outside the research. Then information adoption is 0.380 , means that online information sourceis able to explain the variance of information adoption at $38 \%$, and $62 \%$ is influenced by other variables not found in this study. The value of $\mathrm{R}^{2}$ of purchase intention is 0.411 which means that online information sources, attitudes, and information adoption is able to explain the variance of purchase intention as much as $41.1 \%$, and the rest that is $58.9 \%$ is outside the variables of this study.

\section{Hypothesis Test}

Table 8..Hipotesis Result

\begin{tabular}{|l|l|l|l|l|l|}
\hline \multicolumn{1}{|c|}{ Variable } & \multicolumn{1}{|c|}{$\begin{array}{c}\text { Original } \\
\text { Sample (O) }\end{array}$} & $\begin{array}{c}\text { Sample } \\
\text { Mean } \\
(\mathbf{M})\end{array}$ & $\begin{array}{c}\text { Standard } \\
\text { Deviation } \\
\text { (STDEV) }\end{array}$ & $\begin{array}{c}\text { T Statistics } \\
(\mid \mathbf{O} / \text { STDEV })\end{array}$ & $\begin{array}{c}\text { P } \\
\text { Values }\end{array}$ \\
\hline $\begin{array}{l}\text { Online Information } \\
\text { Source (X) } \rightarrow \text { Purchase } \\
\text { Intention (Y) }\end{array}$ & 0.536 & 0.545 & 0.051 & 10.514 & 0.000 \\
\hline $\begin{array}{l}\text { Online Information } \\
\text { Source (X) } \rightarrow \text { Attitude } \\
\text { (Z1) }\end{array}$ & 0.570 & 0.575 & 0.069 & 8.271 & 0.000 \\
\hline $\begin{array}{l}\text { Online Information } \\
\text { Source (X) } \rightarrow \\
\text { Information Adoption } \\
\text { (Z2) }\end{array}$ & 0.548 & 0.557 & 0.053 & 10.342 & 0.000 \\
\hline $\begin{array}{l}\text { Attitude (Z1) } \rightarrow \\
\text { Information Adoption } \\
\text { (Z2) }\end{array}$ & 0.345 & 0.346 & 0.107 & 3.223 & 0.001 \\
\hline $\begin{array}{l}\text { Attitude (Z1) } \rightarrow \text { Purchase } \\
\text { Intention (Y) }\end{array}$ & 0.352 & 0.355 & 0.072 & 4.860 & 0.000 \\
\hline $\begin{array}{l}\text { Information Adoption } \\
\text { (Z2) } \rightarrow \text { Purchase } \\
\text { Intention (Y) }\end{array}$ & 0.253 & 0.258 & 0.068 & 3.688 & 0.000 \\
\hline
\end{tabular}




\section{International Journal of Business Management and Economic Review}

Vol. 2, No. 06; 2019

ISSN: 2581-4664

The first hypothesis is accepted that is online information source influences purchase intention because it has a coefficient of 0.536 , a t-statistic value $>t$-table is 10.514 and a p-value of 0.000 where < of 0.05.This means that This indicates that the higher the use of online information source, the higher the level of consumer purchase intention.

The second is also accepted that is online information source influences attitude, because the coefficent is 0.570 , and t-statistics $>t$-table that is equal to 8271 . This indicates that the higher the use of online information source, the higher the consumer's positive attitude toward car purchase intentions.

The third hypothesis is accepted that is online information source influences information adoption because it has the coefficient value of 0.548 and t-statistic value $>t$-table of 10.342 and p-value of $0.000<0.05$. This describes that the better and more complete the information provided, the more positive the consumer's attitude towards information and adopting that information.

The fourth hypothesis is accepted as well that is attitude influences the information adoption with the coefficient value is 0.345 , and the value of $t$-statistics $>t$-table, that is 3.223 . This explains that the better the attitude of consumers, the higher the information adoption they have.

The fifth hypothesis is accepted as well that is attitude influences the purchase intention with the coefficient value is 0.352 , and the value of t-statistics> t-table, that is 4.860 .This explains that the better the attitude of consumers, the higher the purchase intention they have.

The sixth hypothesis is accepted too that is information adoption influences purchase intention with the coefficient value is 0.253 , $t$-statistic value $>\mathrm{t}$-table that is 3.688 , and the $\mathrm{p}$ value is $0.000<0.05$. This figures that the better the adoption of information obtained by consumers, the higher the purchase intention they have.

All the hypotheses are with the acceptance results. This is in accordance with the previous theories existing, then all the results are fit and proven.

\section{CONCLUSIONS}

The result shows that online information source influences purchase intention significantly, online information source influences attitude significantly, online information source influences information adoption significantly, attitudes influences purchase intention significantly, attitudes influences purchase intention significantly, and information adoption influences purchase intention significantly. These findings contribute to the realm of science that succeed building the model, and can be a reference to develop another model in the further. The originality rests in the combination of the causality theories form the previous, and uses SEM-Partial Least Square as a statistic test technique.The limitation resides in the amount of the variables and object.

The results also contribute to the practical persons, especially for the car companies. The result descibes that in purchasing decisions for luxury goods such as cars, consumers will pass a complete purchase stage, one of which is finding information. The information related to the choice of other brands and information about savings, equipment, specifications, features of a car, and also compared prices are used either from the online sources or offline sources. Online information sources including e-WOM, neutral websites, and producer websites have an important role in purchase intention. 


\section{International Journal of Business Management and Economic Review}

Vol. 2, No. 06; 2019

ISSN: 2581-4664

So the car companies need to pay attention in increasing their promotional activities through online information sources so that consumers can more easily obtain information and are confident in forming purchase intentions. In addition, it also needs to influence people's attitudes by the company's online information sources, by explaining that the company is complete, easy, and trustworthy.

\section{REFERENCES}

Abdillah, W. and Jogiyanto (2015) Partial Least Square (PLS): Alternative Structural Equation Modelling (SEM) Dalam Penelitian Bisnis. Yogyakarta: Andi Publisher.

Alboqami, H. et al. (2015) 'Electronic word of mouth in social media: The common characteristics of retweeted and favourited marketer-generated content posted on Twitter', Int. J. Internet Marketing and Advertising, 9(4), pp. 338-357. doi: 10.1504/IJIMA.2015.072886.

Cakdan (2013) Internet Jadi Referensi Utama Pembeli Mobil. Available at: https://cakdan.com/2013/10/08/internet-jadi-referensi-utama-pembeli-mobil/ (Accessed: 28 October 2018).

Charo, N. et al. (2015) 'Determining the Impact of Ewom on Brand Image and Purchase Intention through Adoption of Online Opinions', 3(1).

Chen, J. et al. (2016) 'The effect of online information sources on purchase intentions between consumers with high and low susceptibility to informational influence', Journal of Business Research. Elsevier Inc., 69(2), pp. 467-475. doi: 10.1016/j.jbusres.2015.05.003.

Cheung, C. M. K. and Thadani, D. R. (2012) 'The impact of electronic word-of-mouth communication: A literature analysis and integrative model', Decision Support Systems. Elsevier B.V., 54(1), pp. 461-470. doi: 10.1016/j.dss.2012.06.008.

Dwipayani, N. and Rahyuda, I. (2016) 'Pengaruh sikap dan fashion leadership terhadap niat beli online remaja di Kota Denpasar', E-Jurnal Manajemen Universitas Udayana, 5(6), pp. $3620-3646$.

Erkan, I. and Evans, C. (2016) 'Computers in Human Behavior The influence of eWOM in social media on consumers ' purchase intentions: An extended approach to information adoption', Computers in Human Behavior. Elsevier Ltd, 61, pp. 47-55. doi: 10.1016/j.chb.2016.03.003.

F. Hair Jr, J. et al. (2014) 'Partial least squares structural equation modeling (PLS-SEM) An emerging tool in business research', European Business Review. Emerald Group Publishing Limited, 26(2), pp. 106-121.

Farid and Yanti, I. (2018) 'Perbedaan EWOM Kualitas Informasi, Krediilitas Informasi, Kegunaan Informasi, dan Adopsi Informasi Antara Media Sosial dan Situs Belanja Pada Niat Pembelian Produk Fashion', Jurnal Manajemen dan Inovasi, 9(1), pp. 47-59.

Filieri, R. (2015) 'What makes online reviews helpful? A diagnosticity-adoption framework to explain informational and normative influences in e-WOM What makes online reviews helpful? A diagnosticity-adoption framework to explain informational and normative influences in e', Journal of Business Research. Elsevier Inc., 68(6), pp. 1261-1270. doi: 10.1016/j.jbusres.2014.11.006.

Hwang, K. and Zhang, Q. (2018) 'Influence of paraocial elationhip between digital celebrities and their follower on follower purchase and electronic word of mouth intention and 


\section{International Journal of Business Management and Economic Review}

Vol. 2, No. 06; 2019

ISSN: 2581-4664

persuasion knowledge', Computers in Human Behavior. Elsevier B.V., 87, pp. 155-173. doi: 10.1016/j.chb.2018.05.029.

Imari, S., Lubis, P. H. and Chen, S. (2017) 'Pengaruh Orientasi Belanja Kepercayaan Online dan Pengalaman Pembelian Sebelumnya Terhadap Niat Pembelian Konsumen Secara Online dengan Perbedaan Gender Sebagai Variabel Pemoderasi', Jurnal Magister Manajemen2, $1(1)$.

Kinnear, T. C. and Taylor, J. R. (2002) Riset pemasaran : pendekatan terpadu. Edited by alih bahasa Y. Lamarto. Jakarta: Erlangga.

Kotler, P. and Keller, K. L. (2018) Marketing Management, Global Edition. 15th editi. Harlow, United Kingdom: Pearson.

Kurniawan, A. (2005) Transformasi pelayanan publik. Jakarta: Pembaruan.

Mahkota, A. P., Suyadi, I. and Riyadi (2014) 'Pengaruh Kepercayaan dan Kenyamanan terhadap Keputusan Pembelian Online (Studi pada Pelanggan Website Ride Inc)', Jurnal Administrasi Bisnis, 8(2), pp. 1-7.

Marticotte, F. and Arcand, M. (2017) 'Schadenfreude, attitude and the purchase intentions of a counterfeit luxury brand', Journal of Business Research. Elsevier Inc. doi: 10.1016/j.jbusres.2016.12.010.

Martins, J. et al. (2019) 'How smartphone advertising influences consumers' purchase intention', Journal of Business Research. Elsevier, 94(January), pp. 378-387. doi: 10.1016/j.jbusres.2017.12.047.

Mccole, P., Ramsey, E. and Williams, J. (2010) 'Trust considerations on attitudes towards online purchasing : The moderating effect of privacy and security concerns', Journal of Business Research. Elsevier Inc., 63(9-10), pp. 1018-1024. doi: 10.1016/j.jbusres.2009.02.025.

Meskaran, F., Ismail, Z. and Shanmugam, B. (2013) 'Online Purchase Intention: Effects of Trust and Security Perception', Australian Journal of Basic and Applied Sciences, 7(6), pp. 307315.

Peter, J. P. and Olson, J. C. (2013) Perilaku Konsumen dan Strategi Pemasaran, Jakarta: Erlangga. Jakarta: Salemba Empat.

Sreen, N., Purbey, S. and Sadarangani, P. (2018) 'Impact of culture, behavior and gender on green purchase intention', Journal of Retailing and Consumer Services. Elsevier Ltd, 41(July 2017), pp. 177-189. doi: 10.1016/j.jretconser.2017.12.002.

Sussman, S. W. and Siegal, W. S. (2003) 'Informational influence in organizations: An integrated approach to knowledge adoption', Information Systems Research, 14(1), pp. 4765. doi: $10.1287 /$ isre.14.1.47.14767.

Thuarau, T. H. et al. (2004) 'Electronic Word of Mouth Via Consumer-Opinion Platform: What Motivates Consumers to Articulate Themselves on The Internet?', Journal of Interactive Marketing, 18(1), pp. 38-52. doi: 10.1002/dir.10073.

Utami, P., Ma'ruf, J. J. and Utami, S. (2017) 'Pengaruh Brand Origin, Brand Credibility, SelfImage Congruence Terhadap Purchase Intention dengan Brand Knowledge Sebagai Pemoderasi Pada Smartphone Samsung Android di Banda Aceh', Jurnal Perspektif Manajemen dan Perbankan, 8(3), pp. 71-94.

Wang, T. et al. (2016) 'What drives electronic word-of-mouth on social networking sites? Perspectives of social capital and self-determination', Telematics and Informatics, 33(4), pp. 1034-1047. doi: https://doi.org/10.1016/j.tele.2016.03.005. 
International Journal of Business Management and Economic Review

Vol. 2, No. 06; 2019

ISSN: 2581-4664

Yani, H., Ceng, L. and Priskilla, R. (2013) 'Online Consumer Behavior: Confirming The AISAS Model on Twitter Users', in International Conference on Social and Political Sciences (ICSPS). West Java. Available at: http://icsps.event.uinjkt.ac.id/about/.

Zhang, W. and Watts, S. a. (2008) 'Capitalizing on Content: Information Adoption in Two Online communities', Journal of the Association for information systems, 9(2), pp. 73-94. doi: Article. 